\title{
Antioxidant And DNA Damage Preventive Properties of Bacopa Monniera (L) Wettst.
}

\author{
Anand. T*, Mahadeva Naika, Swamy MSL, Farhath Khanum \\ Biochemistry \& Nutrition Discipline, Defence Food Research Laboratory, Siddarthanagar, Mysore-570011, India.
}

\begin{abstract}
Background: Bacopa monniera (L.) Wettst. is a perennial creeping plant found throughout India in wet, damp and marshy areas. Traditionally, it was used as a brain tonic to enhance memory development, learning and concentration and to provide relief to patients with anxiety or epileptic disorders. Objective: Extraction and estimation of antioxidant and DNA damage preventive activity of $B$. monniera. Materials and Methods: The present study was to assess the antioxidant potential in vitro of extracts of $B$. monniera in different solvents like hexane, chloroform, ethyl acetate, acetone, methanol and water. Total polyphenols content of each extract was determined using folin-ciocalteu reagent. The antioxidant activity of different extracts was checked on the basis of 1,1 diphenyl-2-picrylhydrazyl (DPPH) free radical scavenging activity, hydroxyl radical scavenging activity and reducing power assay. DNA damage preventive property of Bacopa monniera was checked using pRSETA plasmid grown in E. coli. Results: Highest polyphenol content was found in methanol extract followed by water extract $\left(55.0 \mu \mathrm{g} / \mathrm{mg}, 52.0 \mu \mathrm{g} / \mathrm{mg}\right.$ gallic acid equivalents respectively). The IC ${ }_{50}$ values of the DPPH and hydroxyl radical scavenging activities of methanol extract showed $0.052 \mathrm{mg} / \mathrm{ml}$ and $0.034 \mathrm{mg} / \mathrm{ml}$ respectively. Reducing power assay results also followed in the same way. Methanol extract was comparatively effective in preventing more DNA damage. Conclusion: The results obtained in this study clearly indicate that B.monniera has a significant potential as a natural anti-oxidant and DNA damage preventing agent.
\end{abstract}

Keywords: Anti-oxidant; DPPH; Bacopa monniera; DNA damage; Poly phenols

Correspondence: Ph. +91 8212473290 Extn: 352 ; FAX: +91 8212473468

E-mail: ananddfrl@yahoo.com

\section{INTRODUCTION}

Bacopa monniera (L.) Wettst. (Scrophulariaceae), also referred to as water hyssop, and "Brahmi," has been in use since time immemorial as nerve tonic for improvement of memory. B. monniera is a perennial creeping plant found throughout India in wet, damp and marshy areas. ${ }^{[1-2]}$ The plant has been used in Indian folklore as a nerve tonic. ${ }^{[3]}$ Traditionally, it was used as a brain tonic to enhance memory development, learning and concentration ${ }^{[4]}$ and to provide relief to patients with anxiety or epileptic disorders. ${ }^{[5]}$ Alcoholic extract of B. monniera has shown cognition facilitating effect in normal rats ${ }^{[6]}$ and in different behavioral response studies ${ }^{[7]}$ and also inhibited the amnesic effects of scopolamine, electroshock and immobilization stress. ${ }^{[8]}$ B. monniera extract shown phenytoin- induced cognitive deficit in mice by both acquisition and retention of memory without affecting its anticonvulsant activity. ${ }^{[0]}$

Bacopa extract contains two prominent constituents namely, bacoside-A ${ }^{[10-11]}$ and bacoside-B. ${ }^{[11-12]}$ It has also been shown to exert antioxidant effects through the chelating of metal ions, breaking oxidative chain reaction, ${ }^{[13]}$ improving activities of anti oxidative defense enzymes such as superoxide dismutase (SOD), catalase (CAT) and glutathione peroxidase (GPx), ${ }^{[14]}$ and scavenging other free radicals. ${ }^{[15]}$ It also exhibits antistress activity in rat by modulating the activities of Hsp70, P450, and $\mathrm{SOD},{ }^{[16]}$ repairing the damaged neurons by enhanced kinase activity, neuronal synthesis coupled with restoration of synaptic activity, and nerve impulse transmission. ${ }^{[17]}$

Synthetic antioxidants like butylated hydroxytoluene (BHT) and butylated hydroxyanisole (BHA) commonly used in processed foods have side effects and are carcinogenic. ${ }^{[18]}$ In recent years, the use of natural antioxidants present in food and other biological materials has attracted considerable interest due to their presumed safety, nutritional and therapeutic value. Epidemiological and in vitro studies strongly suggest that food containing phytochemicals with antioxidants have potentially protective effects against many diseases, including cancer, diabetes and cardiovascular diseases. ${ }^{[19]}$ Plant and plant products are being used as a source of medicine since long. The medicinal properties of plants have been 
investigated in the recent scientific developments throughout the world, due to their potent antioxidant activities, no side effects and economic viability. ${ }^{[20]}$ Phenolic and flavonoid compounds widely distributed in plants which have been reported to exert multiple biological effect, including antioxidant, free radical scavenging abilities, anti-inflammatory, anticarcinogenic etc. $^{[21]}$

Nowadays, there is an increasing interest in the biochemical functions of natural antioxidant extracts from vegetables, fruits and medicinal plants, which can become candidates to prevent oxidative damage, promoting health. The phenolic constituents found in vegetables have received considerable attention for being the main components of antioxidant activity, in spite of not being the only ones. The antioxidant activity of phenolic constituents has been attributed to its oxidereduction properties, which play an important role in the adsorption or neutralization of free radicals. ${ }^{[2]}$

Based on its reputation to improve health condition Bacopa monniera has been selected for the present study and evaluated for its antioxidant properties and DNA damage prevention using various in vitro systems.

\section{MATERIALS AND METHODS}

\section{Plant material}

Bacopa monniera (L) Wettst. aerial plant material was collected from the foot hills of Tirumala, Tirupati, Andhra Pradesh, India, and identified with the help of herbarium collection, Department of Botany, Sri Venkateswara University, Tirupati, Andhra Pradesh. The plant material was allowed to dry in shade for three days. The shade dried plant material was taken for further studies.

\section{Chemicals and reagents}

Hexane, chloroform, ethyl acetate, acetone, methanol and distilled water were used as solvent for extraction of antioxidant compounds. Other solvents and chemicals used in this study were dimethyl sulphoxide (DMSO), petroleum ether $\left(40-60^{\circ} \mathrm{C}\right), \mathrm{H}_{2} \mathrm{SO}_{4}, \mathrm{NaOH}, \mathrm{HCl}, \mathrm{H}_{3} \mathrm{BO}_{3}$, DPPH (1,1,Diphenyl 1-2,picryl hydrazyl), BHA, Gallic acid, Folin-Ciocalteu reagent, $\mathrm{FeCl}_{2}$, ferrozine, potassium ferricyanide, NaEDTA, ascorbic acid, TCA, $\mathrm{FeCl}_{3}$, $\mathrm{Na}_{2} \mathrm{CO}_{3}$, catechin, deoxyribose, $\mathrm{H}_{2} \mathrm{O}_{2}$, thiobarbituric acid (TBA). All the chemicals and reagents were of analytical grade and were stored at prescribed conditions in the laboratory.

\section{Sequential extraction}

Fifty gram of crushed leaf sample was taken for extraction procedure. Cold extraction method was followed for sequential extraction of Bacopa from non polar to polar solvents viz., hexane, chloroform, ethyl acetate, acetone, methanol and water. The extract was filtered through whatman No.1. The filtrate was flash evaporated using a round bottom flask of known weight. Each of the extract was weighed and total yield was calculated for each solvent system. A known weight of each dried extract was dissolved in the respective solvents to prepare a stock solution of $100 \mathrm{mg} / \mathrm{ml}$. All the stock solutions were kept at $4^{\circ} \mathrm{C}$ until further use.

\section{Total polyphenols estimation}

Total polyphenols content of each extract was determined using folin-ciocalteu reagent (FC reagent) method of Singleton \& Rossi. ${ }^{[23]}$ Briefly, sample in different amounts was mixed with distilled water to make up final volume (3 $\mathrm{ml})$. Then, $0.5 \mathrm{ml} \mathrm{FC}$ reagent was mixed and incubated for $10 \mathrm{~min}$ at room temperature. Two milliliter $7 \% \mathrm{Na}_{2} \mathrm{CO}_{3}$ was added and boiled the content in a boiling water bath for one minute. After cooling, absorbance was measured at $650 \mathrm{~nm}$ (there is no distinct absorbance maximum wavelength for polyphenols, so $650 \mathrm{~nm}$ wavelength was used). Gallic acid was used as a standard and amount of total polyphenols content was expressed as $\mu \mathrm{g}$ gallic acid equivalent per milligram ( $\mu \mathrm{g} \mathrm{GAE} / \mathrm{mg}$ ) extract.

\section{DPPH radical scavenging activity}

The antioxidant activity of different extracts was checked on the basis of 1, 1 diphenyl-2-picrylhydrazyl (DPPH) free radical scavenging activity. DPPH assay was performed as per the method described by Eberhardt et al., ${ }^{[24]} \mathrm{DPPH}(500 \mu \mathrm{l}, 0.5 \mathrm{mM}$ in methanol) solution was mixed with different amounts of sample and volume was made to $3.5 \mathrm{ml}$ with methanol. The mixture was incubated in dark for $45 \mathrm{~min}$ at room temperature. Absorbance was recorded at $515 \mathrm{~nm}$ in a spectrophotometer. BHA was used as standard antioxidant compound. A positive control was prepared by mixing $3 \mathrm{ml}$ methanol and 0.5 $\mathrm{ml}$ of DPPH solution. Sample blanks were prepared in methanol without DPPH solution to eliminate the absorbance of crude extracts. Methanol was used as blank. The DPPH radical scavenging activity percentage was calculated by using the formula as given below:

$\mathrm{DPPH}^{\circ}$ scavenging activity $(\%)=\left[\frac{\left(\mathrm{A}_{\mathrm{c}}-\mathrm{A}_{\mathrm{s}}\right)}{\mathrm{A}_{\mathrm{c}}}\right] \times 100$ 
Where $A_{c}$ is the absorbance of positive control solution and $\mathrm{A}_{\mathrm{s}}$ is the absorbance of test solution. $\mathrm{IC}_{50}$ value, the concentration of sample or extract required to scavenge $50 \%$ of the DPPH free radicals in the mixture, was calculated using a linear regression equation derived from the graph of $\% \mathrm{DPPH}$ scavenging activity and sample concentration.

\section{Hydroxyl radical scavenging activity}

Deoxyribose degradation assay was performed as per the method of Halliwell et al., ${ }^{[25]}$ with slight modification. Briefly, different concentrations of extracts were mixed

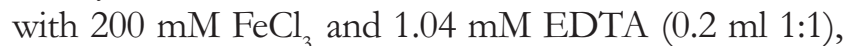
$1 \mathrm{mM} \mathrm{H}_{2} \mathrm{O}_{2}(0.1 \mathrm{ml}), 28 \mathrm{mM}$ deoxyribose $(0.1 \mathrm{ml})$ and $1 \mathrm{mM}$ ascorbic acid $(0.1 \mathrm{ml})$ and the final volume was made to $1.1 \mathrm{ml}$ with phosphate buffer $(0.2 \mathrm{mM}, \mathrm{pH}=$ 7.2). The mixture was incubated at $37^{\circ} \mathrm{C}$ for $1 \mathrm{~h}$. Then, $1 \mathrm{ml}$ of thiobarbituric acid $(1 \%$ in $50 \mathrm{mM} \mathrm{NaOH})$ and $1 \mathrm{ml}$ of $5 \%$ TCA was added followed by boiling in a boiling water-bath for $20 \mathrm{~min}$. After cooling, absorbance of the mixture was measured at $532 \mathrm{~nm}$ and the percentage inhibition was calculated.

\section{Total reducing power estimation}

The total reducing power of different extracts was determined following the method of Oyaizu. ${ }^{[26]}$ Different amount of extract was mixed with equal volume of phosphate buffer $(2.5 \mathrm{ml}, 0.2 \mathrm{M}, \mathrm{pH}$ 6.6) and potassium ferricyanide $(2.5 \mathrm{ml}, 1 \%)$. The mixture was incubated at $50^{\circ} \mathrm{C}$ for $20 \mathrm{~min}$. A portion $(2.5 \mathrm{ml})$ of trichloroacetic acid $(10 \%)$ was added to the mixture followed by centrifugation at $3000 \mathrm{rpm}$ for $10 \mathrm{~min}$. A $2.5 \mathrm{ml}$ portion of supernatant was mixed with $2.5 \mathrm{ml}$ of distilled water and $0.5 \mathrm{ml}$ of $0.1 \% \mathrm{FeCl}_{3}$. The absorbance was measured at $700 \mathrm{~nm}$. Increased absorbance of the reaction mixture indicated increased reducing power.

\section{DNA damage protective activity}

DNA damage preventive property of Bacopa monniera was checked using pRSETA plasmid grown in E. coli. Plasmid DNA was isolated using QIA prep Spin Mini prep kit. Plasmid DNA was oxidized with $\mathrm{H}_{2} \mathrm{O}_{2}+$ UV treatment in presence of plant extract (PE) and checked on 1\% agarose according to Russo et al. ${ }^{[15]}$ with minor modifications. In brief, the experiment was performed in a $10 \mu \mathrm{l}$ in a micro centrifuge tube containing $200 \mathrm{ng}$ of pRSETA plasmid DNA in TE buffer $(10 \mathrm{mM}$ Tris-Cl and $1 \mathrm{mM}$ EDTA) $\mathrm{pH}$ 8.0. $\mathrm{H}_{2} \mathrm{O}_{2}$ was added at final concentration of $10 \mathrm{mM} / \mathrm{ml}$ with various concentrations of plant extracts ( $1 \mu \mathrm{l} \mathrm{of} 10 \mathrm{mg} / \mathrm{ml}$ concentration). Along with plant extract, known antioxidants such as quercetin and gallic acid were also used at the concentration of 100 $\mu \mathrm{m}$. The reactions were initiated by UV irradiation and continued for $5 \mathrm{~min}$ on the surface of a UV transilluminator $(312 \mathrm{~nm})$ under room temperature. After irradiation the reaction mixture along with gel loading dye $(6 \mathrm{X})$ was loaded on to $1 \%$ agarose gel and run at $200 \mathrm{v}$ for $1 \mathrm{hr}$. Untreated pRSETA plasmid DNA was used as a positive control in each run of gel electrophoresis.

\section{RESULTS AND DISCUSSION}

\section{Total polyphenols}

Plant phenolics constitute one of the major groups of compounds acting as primary antioxidants or free radical terminators. Phenolics are ubiquitous secondary metabolites in plants and possess a wide range of therapeutic uses such as antioxidant, antimutagenic, anticarcinogenic and anti-inflammatory, prevention of low density lipoprotein oxidation, free radical scavenging activities and also decrease cardiovascular complications. ${ }^{[27]}$ In the present study it was found that highest polyphenols content was in methanol extract $(55.0 \mu \mathrm{g} / \mathrm{mg})$ followed by water extract $(52.0 \mu \mathrm{g} / \mathrm{mg})$, followed by chloroform $(35.0 \mu \mathrm{g} / \mathrm{mg}$ ) (Fig. 1). It is known that poly phenolic compounds have inhibitory effects on mutagenesis and carcinogenesis in humans when ingested up to $1 \mathrm{~g}$ daily from a diet rich in fruits and vegetables. ${ }^{[28]}$ However, the activity of synthetic anti oxidants was often observed to be higher than that of natural anti-oxidants. ${ }^{[29]}$

\section{DPPH radical scavenging activity}

Determination of antioxidant activity of different solvent extracts of Bacopa was based on DPPH radical scavenging activity. The reduction capability of DPPH radicals was determined by the decrease in its absorbance at $515 \mathrm{~nm}$ induced by antioxidants. On the DPPH radical, methanol fraction had significant scavenging effects with increasing concentration in the range of $0.1-0.8 \mathrm{mg} / \mathrm{ml}$ when compared with that of BHA. The $\mathrm{IC}_{50}$ values were found with $0.052 \mathrm{mg} / \mathrm{ml}$ and $0.42 \mathrm{mg} / \mathrm{ml}$ for methanol fraction and BHA respectively. The DPPH activity of methanol fraction was found to increase in dose dependent manner. The antioxidant activity of different extracts was calculated as their capacity to scavenge free radicals of $\mathrm{DPPH}$, which has been widely used to evaluate the antioxidant activity of natural products from plant and 
microbial sources. ${ }^{[30]}$ Although radical scavenging activity should not be considered as being synonyms with antioxidant activity, it is a fact that almost all of the powerful natural antioxidants, such as tocopherol, carnosal and ascorbic acid are also strong scavengers of the DPPH radical. Thus, good activity in this test is also an indication of the presence of possible antioxidants. All the six extracts were used to check DPPH activity and $\mathrm{IC}_{50}$ values were calculated using regression equations derived from graph shown in Fig. 2A-F The $\mathrm{IC}_{50}$ values clearly indicate that methanol fraction has highest free radical scavenging activity while hexane fraction is least potent. The highest free radical scavenging activity of methanol extract can be attributed to the presence of polyphenols as this fraction contains maximum amount of these secondary metabolites.

\section{Hydroxyl radical scavenging activity}

The hydroxyl radical is an extremely reactive free radical formed in biological systems and has been implicated as a highly damaging species in free radical pathology, capable of damaging almost every molecule found in living cells. ${ }^{[1]}$ The highly reactive hydroxyl radicals can cause oxidative damage to DNA, lipids and proteins. The Fentone reaction generates hydroxyl radicals $(\mathrm{OH})$ which degrade DNA deoxyribose, using $\mathrm{Fe}^{2+}$ salts as an important catalytic component. Oxygen radicals may attack DNA either at the sugar or the base, giving rise to a large number of products.

Hydroxyl radicals are most reactive ROS, capable of attacking most of the biological substrates. The prevention of such deleterious effect is very necessary in terms of both human health and the self-life of food, cosmetics and pharmaceuticals. So, it was considered important to assess the protective ability of the sample extract against $\mathrm{OH}$ radicals. In the $\mathrm{OH}$ radical mediated 2-deoxy ribose degradation assay, $\mathrm{OH}$ radicals are generated by Fenton chemistry using EDTA, $\mathrm{Fe}^{3+}$ ions, ascorbic acid and $\mathrm{H}_{2} \mathrm{O}_{2}$. The $\mathrm{OH}$ radicals degrade the 2 - deoxy ribose molecule into 2-thiobarbituric acid reactive substances (TBARS), which can be quantified spectrophotometrically at 532 $\mathrm{nm}$. Methanol and water extracts showed more or less similar hydroxyl radical scavenging activity i.e. $\mathrm{IC}_{50}=0.345$ and $0.350 \mathrm{mg} / \mathrm{ml}$ respectively, remaining all extracts showed their $\mathrm{IC}_{50}$ values in between 0.45 to $0.60 \mathrm{mg} / \mathrm{ml}$ (Fig. 3).

\section{Total reducing power}

Ferric ion reduction to ferrous ion reducing power was observed more in methanol extract followed by water extract and least power in hexane fraction (Fig. 4).

\section{DNA damage protective activity}

DNA damage protection studies were performed using methanol extract and water extract. Protection of DNA strand breaks was observed more in methanol extract followed by water extract. Fig. 5A \& B showed protection of super coiled plasmid is directly proportional to the activity of plant extract. Well known anti-oxidants such as gallic acid and quercetin did not protect the DNA damage at the concentration of $100 \mathrm{mM}$ in a pure form.

\section{Total Polyphenols present in Brahmi}

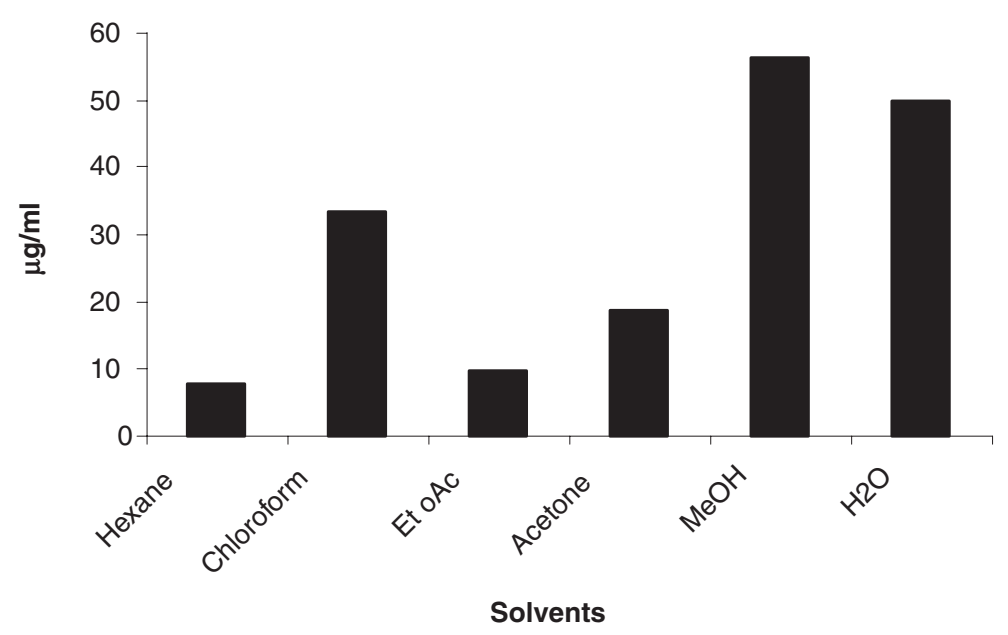

Figure 1. Total polyphenols in different extracts of B. monniera. 
A. Hexane

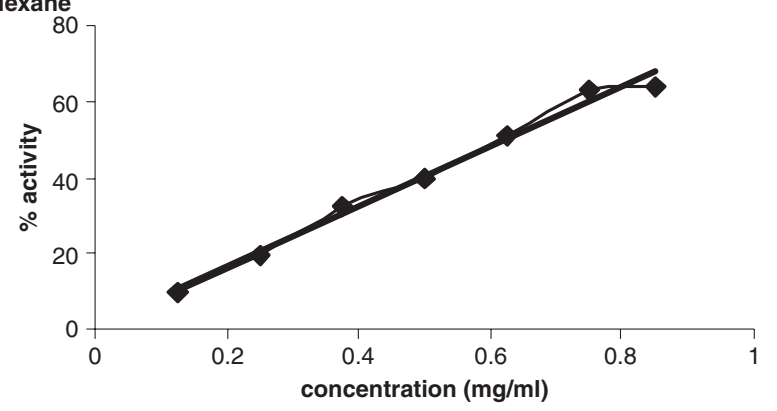

C. Ethyl acetate

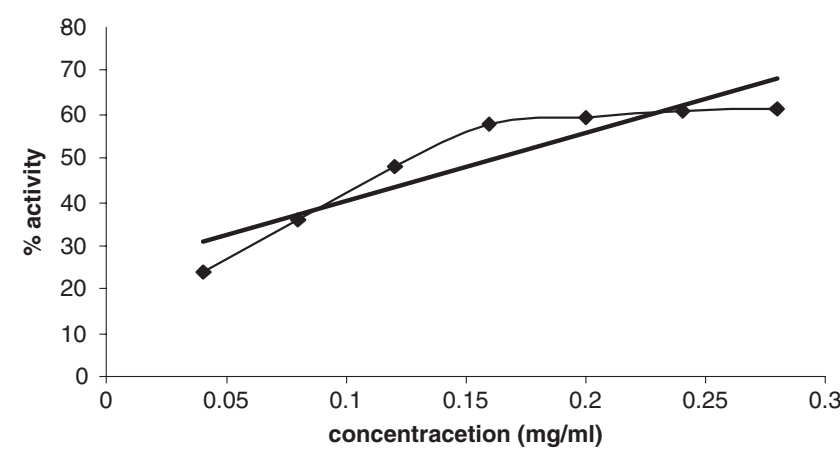

E. Methanol

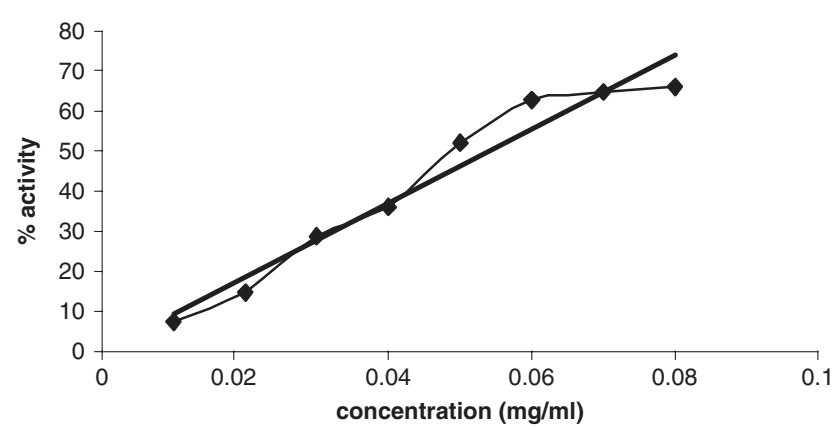

B. Chloroform

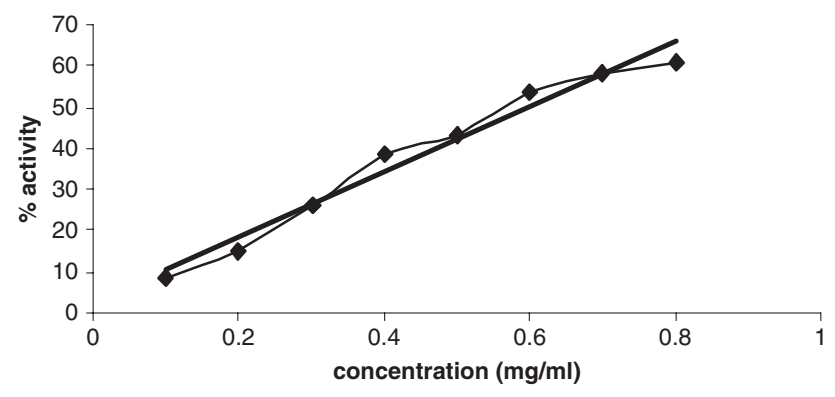

D. Acetone

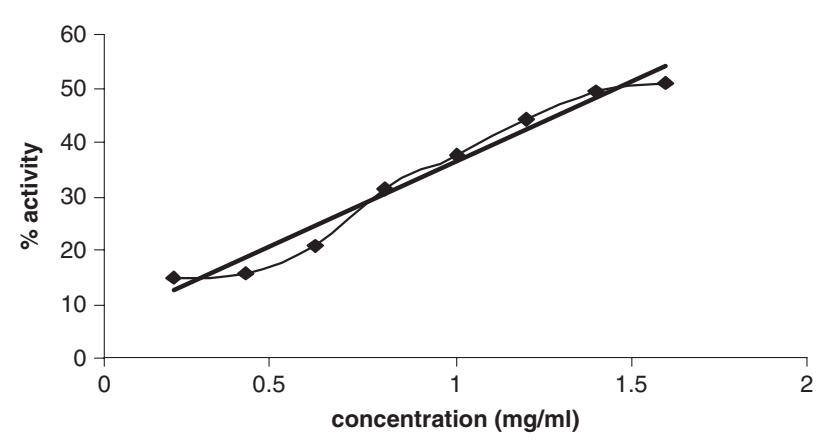

F. Water

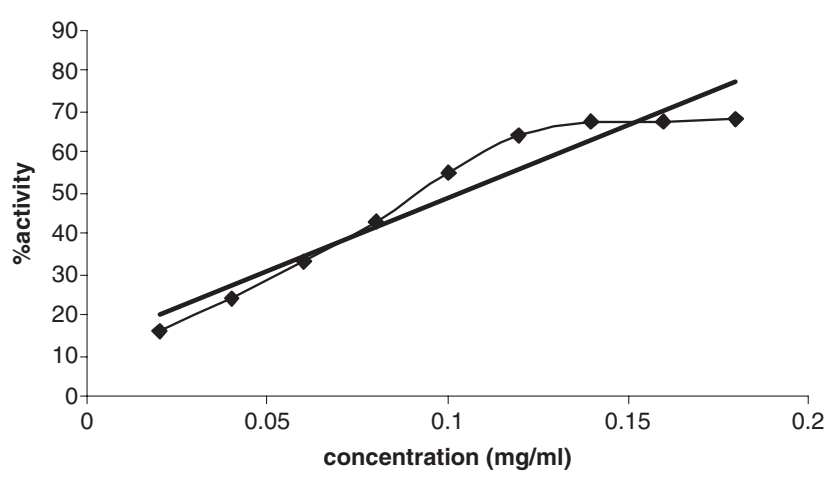

Figure 2. DPPH radical scavenging activity of different extracts of B. monniera.

\section{Hydroxyl radical scavenging activity}

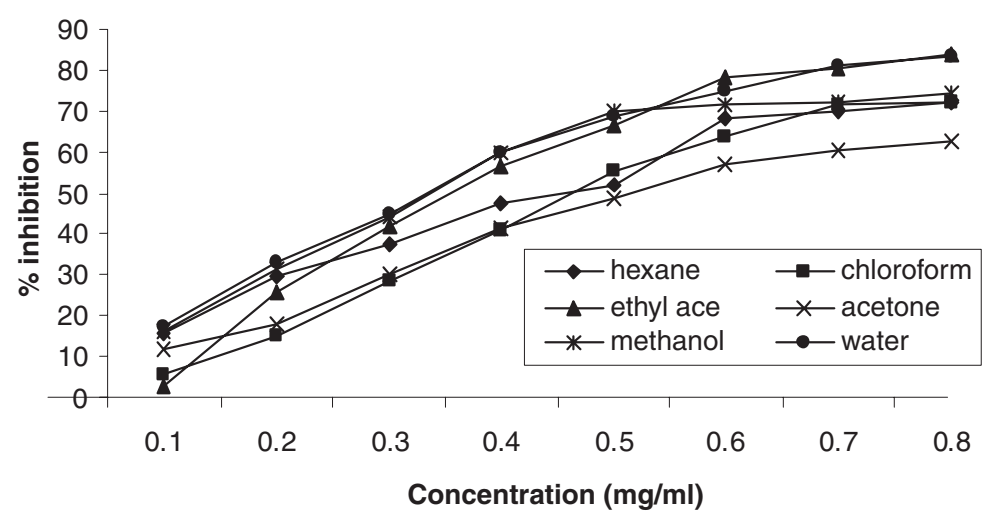

Figure 3. Hydroxyl radical scavenging activity of different extracts of B. monniera. 


\section{Reducing power assay}

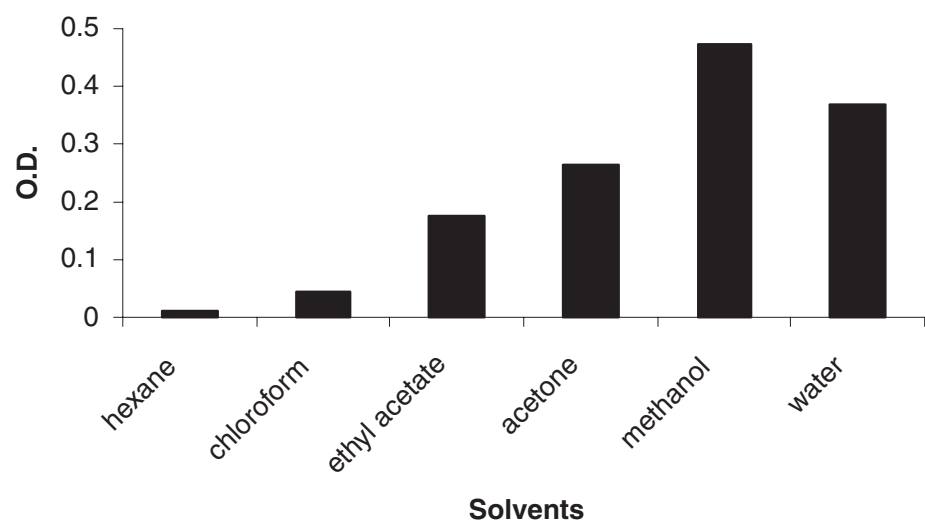

Figure 4. Reducing power activity of different extracts of B. monniera.
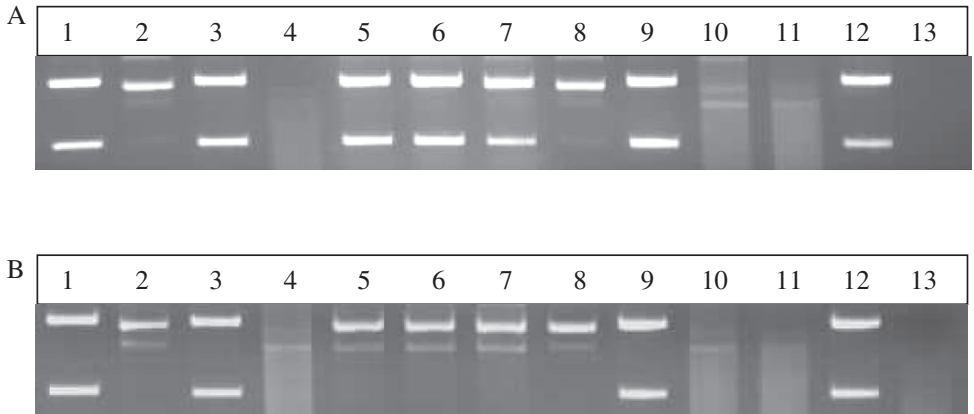

1. Un-treated Plasmid; 2. $\mathrm{H}_{2} \mathrm{O}_{2} ;$ 3. UV-treated; 4. $\mathrm{H}_{2} \mathrm{O}_{2}+$ UV-treated; 5. $\mathrm{H}_{2} \mathrm{O}_{2}+$ PE; 6. $\mathrm{UV}+\mathrm{PE} ;$ 7. $\mathrm{H}_{2} \mathrm{O}_{2}+\mathrm{UV}+\mathrm{PE} ; 8 . \mathrm{H}_{2} \mathrm{O}_{2}+$ Quer; 9. UV + Quer; $10 . \mathrm{H}_{2} \mathrm{O}_{2}+\mathrm{UV}$ + Quer; 11. $\mathrm{H}_{2} \mathrm{O}_{2}+\mathrm{GA} ;$ 12. UV + GA; 13. $\mathrm{H}_{2} \mathrm{O}_{2}+\mathrm{UV}+\mathrm{GA}$. PE: A-Methanol; B-Water.

Figure 5A \& B. DNA damage protection by B. monniera methanol and water extracts.

The faster moving prominent band (lane. 1) corresponded to the native super coiled circular DNA (Sc DNA) and the slower moving band was the open circular form (Oc DNA). The UV irradiation of DNA in the presence of $\mathrm{H}_{2} \mathrm{O}_{2}$ (lane. 2) resulting the cleavage of Sc DNA to give prominent Oc DNA indicating that $\mathrm{OH}$ - generated from UV-photolysis of $\mathrm{H}_{2} \mathrm{O}_{2}$ produced DNA stand scission. This damage can be reduced in the presence of plant extracts (lane 5).

\section{CONCLUSIONS}

Results of the present study showed that methanolic extract of B.monniera possess very pronounced biological properties such as anti oxidant activity, reducing power and DNA damage prevention activity. These results strengthen Bacopa uses not only as memory enhancer but can also be useful for antioxidant activity. Furthermore these results of total polyphenols presence in methanol extract strengthen the biological activity.

\section{ACKNOWLEDGEMENTS}

Authors are thankful to Dr. A.S. Bawa, Director, Defence Food Research Laboratory, Mysore, for his constant encouragement and support to carryout the research work.

\section{REFERENCES}

1. Kirtikar KR., Basu BD. Indian Medicinal Plants. Bhishen Singh and Mehendra Paul Singh, Delhi, 1935. p. 2128.

2. Satyavati GV, Raina MK, Sharma M. Medicinal Plants of India, ICRM, New Delhi. 1976. p. 118-22.

3. Chopra RN, Nayar SL, Chopra IC. Glossary of Indian Medicinal Plants. CSIR, New Delhi, 1956. p. 32.

4. Mukherjee DG, Dey CD. Clinical trial on Brahmi. Ind J Exp Med Sci 1966;10:5-11. 
5. Chopra RN. Indigenous Drugs of India, second ed. U.N. Dhur and Sons, Calcutta, India, 1958. p. 341.

6. Singh HK, Dhawan BN. Drugs affecting learning and memory. Wiley Eastern, New Delhi, 1992. p. 189-207.

7. Singh HK, Dhawan BN. Neuropsychopharmacological effects of the Ayurvedic nootropic Bacopa monniera Linn (Brahmi). Ind J Pharmacol 1997;29:359-65.

8. Dhawan BN, Singh HK. Pharmacological studies on Bacopa monnierian ayurvedic nootropic agent. Eur Neuropsychopharmacol. 1996; 3: 144-150.

9. Vohora D, Pal SN, Pillai KK. Protection from phenytoininduced cognitive deficit by Bacopa monniera, a reputed nootropic plant. J Ethnopharmacol 2000;71:383-90.

10. Chatterii N, Rastogi RP, Dhar ML. Chemical examination of Bacopa monniera Wettst. Part II: The constitution of Bacoside A Indian J Chem. 1965;3:24-9.

11. Singh HK, Rastogi RP, Srimal RC, Dhawan BN. Effects of Bacosides $A$ and $B$ on avoidance response in rats. Phytother Res. 1988;2:70-5

12. Basu N, Rastogi RP, Dhar ML. Chemical examination of Bacopa monniera Wettst Part III: The constitution of Bacoside-B. Indian J Chem, 1967:5:84-9.

13. Tripathi YB, Chaurasia S, Tripathi E, Upadhyay A, Dubey GP. Bacopa monniera Linn. as an antioxidant: mechanism of action. Indian J Exp Biol. 1996;34:523-26.

14. Bhattacharya SK, Bhattacharya A, Kumar A, Ghosal S. Antioxidant activity of Bacopa monniera in rat frontal cortex, striatum and hippocampus. Phytother Res. 2000;14:174-9.

15. Russo A, Izzo AA, Borrelli F, Renis M, Vanella A. Free radical scavenging capacity and protective effect of Bacopa monniera L. on DNA damage. Phytother Res. 2003;17:870-5.

16. Chowdhuri DK, Parmar D, Kakkar P, Shukla R, Seth PK, Srimal RC. Antistress effects of bacosides of Bacopa monnieri: modulation of Hsp70 expression, superoxide dismutase and cytochrome P450 activity in rat brain. Phytother Res. 2002;16:639-45

17. Kishore K, Singh M. Effect of bacosides, alcoholic extract of Bacopa monniera Linn. (brahmi), on experimental amnesia in mice. Indian J Exp Biol. 2005;43:640-5.

18. Ali S, Kasoju N, Luthra A, Singh A, Sharanabasava H, Sahu A, et al. Indian medicinal herbs as sources of antioxidants. Food Res Int. 2008;41:1-15.
19. Senevirathne M, Kim S, Siriwardhana N, Ha J, Lee K, Jeon Y. Antioxidant potential of Ecklonia cava on reactive oxygen species scavenging metal chelating, reducing power and lipid peroxidation inhibition. Food SciTech Int. 2006;12:27-38.

20. Auudy B, Ferreira F, Blasina L, Lafon F, Arredondo F, Dajas R, et al. Screening of antioxidant activity of three Indian medicinal plants, traditionally used for the management of neurodegenerative diseases. J Ethnopharmacol. 2003;84:131-8.

21. Miller A.L. Antioxidant flavonoids: structure, function and clinical usage. Alt Med Rev. 1996;1:103-11.

22. Kumar R, Phani Kumar G, Chaurasia OP. In Vitro Antioxidant Activity of Methanolic Extract Extracts of Rhodiola Imbricata Edgew. Phog J. 2010;2:157-61.

23. Singleton VL, Rossi JA. Colorimetry of total phenolics with phosphomolybdic acid-phosphotungstic acid reagents. Am. J. Enol. Vit. 1965;16:144-58.

24. Eberhardt MV, Lee CY, Liu RH. Antioxidant activity of fresh apple, Nature. 2000;405:903-4.

25. Halliwell B, Gutteridge JMC, Aruoma OI. The deoxyribose method: a simple assay for determination of rate constants for reaction of hydroxyl radical. Anal. Biochem. 1989;165:215-9.

26. Oyaizu M. Studies on product of browning reaction prepared from glucose amine. Japanese J Nutr. 1986;44:307-15.

27. Yen G, Duh P, Tsai C. Relationship between antioxidant activity and maturity of peanut hulls. J Agric Food Chem. 1993;41:67-70.

28. Tanaka M, Kuei CW, Nagashima Y. Application of antioxidative Maillard reaction products from histidine and glucose to sardine products. Nippon Suisan Gakkaishi. 1998;47:1409-14.

29. Ningappa MB, Dinesha R, Srinivas L. Antioxidant and free radical scavenging activities of polyphenol-enriched curry leaf extract (Murraya koenigii L.). Food Chemistry. 2008;106:720-8.

30. Chang ST, Wu JH, Wang SY, Kang PL, Yang NS, Shyur LF. Antioxidant activity of extracts from Acacia Confusa bark and heartwood. J Agri Food Chem. 2001;49:3420-4.

31. Hochestein $P$, Atallah AS. The nature of oxidant and antioxidant systems in the inhibition of mutation and cancer. Mut Res. 1998; 202:363-75. 